Review Article

www.ijrap.net

\title{
AN EDUCATIONAL PROBLEM IN AYURVEDA FIELD - HOW CAN WE SORT OUT IT: A REVIEW
}

\author{
Rapolu Sunil *
}

Assistant Professor, Department of Kriya sharir, OH Nazar Ayurveda College, Surat, Gujarat Affiliated to GAU, India

Received on: 20/06/16 Revised on: 20/07/16 Accepted on: 01/08/16

*Corresponding author

E-mail: rapolusunil@gmail.com

DOI: $10.7897 / 2277-4343.074150$

\begin{abstract}
Ayurveda the divine science, originated over 5000 years ago. Its knowledge is based on different principles like Tridosha, Triguna, Sapta Dhatu, Srotas and so on. They are the fundamental and very deep principle, which mainly based on philosophy and logic. In the recent day due to without inclusion of Ayurveda basic knowledge information in primary to secondary education level and without having proper thinking towards the Ayurveda concepts it causing difficulty to understand the real information that ancient philosophers wanted to convey us through a particular principle. On the other hand the modern science students have a close acquaintance with modern science related concepts right from their primary to secondary education, as a result to understand Ayurveda principles in this scientific era is becoming very difficult in comparison to modern science. So to rule out this travesty there is a need to inclusion of Ayurveda basic concepts in beginning level of the educational system and as well as there is a need of proper integrative approach which may improve our thinking skills towards the ancient science concepts and also make us compatible to use it in our clinical practice for fulfillment of Ayurveda Aim.
\end{abstract}

Keywords: Ayurveda, Education, Integrate, Modern Science, Principle.

\section{INTRODUCTION}

Ayurveda is the India's glorious tradition of health care system dating back from several years, which is mainly Samhita originated knowledge. Ayurveda knowledge is based on the fundamental principles which were developed from a combination of philosophy and clinical practice. Before the 1870 Ayurveda knowledge has been taught to students in the form of the "Gurukul Parampara", in which students initially got the knowledge of literature, grammar and logic from a Teacher which promotes their thinking skill towards the principles and may generate some basic idea regarding that principles and making them familiar with the Ayurveda terminologies right from their initial education. It made them to understand the Ayurveda's philosophical principles and enable them to apply those principles in their clinical practice to fulfill the Aim. In recent scientific era these principles are consider as a ancient and unscientific because they are not in globally accepted language, so after completing the $12^{\text {th }}$ std with science stream when students get in admission in the Ayurveda stream, they become confused by hearing the Ayurveda Terminologies like "Panchabhuta", "Tridosha" and so on. ${ }^{1,2,3}$ Because they are not in close contact with these terminologies right from their Primary to secondary education like an ancient students were, which creating the difficulty to understand the Ayurveda's philosophical principles. In contrary to modern science the students can easily understand the physiological principles like Hemodynamic Principle because they have developed the close acquaintance with the blood viscosity, density and other related terminologies right from their Primary to Secondary Education.

We can rule out the Education related this travesties problem in Ayurveda field by applying the two solutions

- By including the Ayurveda related basic concepts information right from their Primary to secondary education level, so students may develop some basic idea regarding its fundaments and its nomenclatures' before entering the Ayurveda field and it may not create any confusion in students mind after entering in the stream. It can totally possible by the mutual interest and action of the HRD, AYUSH and CCIM. In recent HRD minister has been taken a very effective step of inclusion of the YOGA Subject in 6 to $10^{\text {th }}$ std of all Government schools ${ }^{6}$, in the same way if they include the Ayurveda conceptual knowledge in the School level education that may helpful to students to develop some close acquaintance towards the concepts and which may also helping them to sharp their thinking skills towards ancient science concepts in right way.

- By using the appropriate integrated approach as per need. It totally depends on teachers. As a teacher it is my duty, so I am trying to integrate it as per my knowledge by using the Tridosha Principle.

Three mutually antagonist yet reciprocal biological aspects "Vata", "Pitta" and "Kapha" are incorporated in the Tridosha principle, which corresponds to elements of Air + Ether, Fire, Water + Earth respectively. ${ }^{7}$ Ayurveda medicine is based on these three biological aspects of the body.

Man is the microcosm of the universe, whatever the aspects which are present in the body same are present in the universe vice versa. As per Example, external world is controlled by Moon, Sun and Air by their "Visarga", "Aadan" and "Vikshep" actions respectively and in the same way bodies different complex biological processes are regulated by the "Kapha", "Pitta" and "Vata" respectively. Human bodies "Kapha, "Pitta" and "Vata" are corresponds to universes Moon, Sun and Air. ${ }^{8}$ It means that "Kapha" main function is "Visarga", "Pitta" main function is Aadan and "Vata" main function is "Vikshep". "Visarga" means the growth, support, strength that which holds things together, provide stability in the body and mind, give 
support and make up the bulk of the bodily tissue. Second aspect "Pitta" which main function is "Aadan", which means the metaphors, assimilation in which by undergoing the chemical transformation substance produces the energy which mediate the different biological functions like perception of vision, metabolism, production of bodily heat, regulate the anger, thirst sensations, shines the bodies complexion and by integrating the different senses it promotes the our thinking skill, memory, intelligence. Third aspect "Vata" main function is "Vikshep" that which moves the things. It is the main motivating force behind the other two "Dosha", "Dhatu" and "Mala" which are lame and incapable to move without it, although they have their own normal function but "Vata" is the initiator and activator of those. ${ }^{9}$ It means that whatever the microscopic and gross motions take place in our body like acquiring, carrying the knowledge of different senses and conveying the motor impulse to target organ, transports of the different substances across the cell membrane, circulation of the blood, movement of the ingested food in the gut, excretion of the wastes, regulation of the flexion-extension, inspiratory-expiratory movements and so on.

According to the "Ayurveda Panchabhautic" principle entire world is an interplay of the five elements; Ether, Air, Fire, Water and Earth respectively. These five elements present in each and every aspect of the body and everyone. ${ }^{10}$ So in same way every "Dosha" is the composed of the five basic building block elements. Depending upon of the relative predominance of these elements in infinite variety of proportion each "Dosha" become unique to each other and possess some mutually antagonist yet reciprocal attributes according to predominant element present in them. Attributes are potential energies which express the static nature of the substance. Attributes and actions have a strong relationship with each other. ${ }^{11}$ so Each "Dosha" functions are expressed on the basis of the attributes ascribed to that particular Dosha in relation to the predominance of the element in that particular "Dosha". Predominant Element Present in "Vata" is Ether-Air, in "Pitta" Fire and in "Kapha" Water-Earth. On the basis of these Predominant elements combination "Vata" Possess the Dry, Light, Cold, Rough, Subtle and Mobile, "Pitta" Possess the Hot, Sharp, Light, Liquid, faulty and Oily and "Kapha possess the Heavy, Slow / Dull, Cold, Oily, Liquid, Slimy / Smooth, Dense, Soft, Static, Sticky / Cloudy, Hard and Gross attributes respectively. ${ }^{12}$ Above mentioned "Dosha" actions are expressed by on the basis of the attributes ascribed to that particular "Dosha". Due to ongoing continues metabolic process in our body, "Dosha" and others continues decaying take place, which are replaced by similar Predominant element and attributes constituted ingested food and some time by medicine. For example in emaciation we have used the "Vidari", which is a Water-Earth Predominant "Dravya", Heavy (Guru) in nature, therefore it increases the "Kapha" Dosha in term increase the bulk of the tissue. ${ }^{13}$

\section{Interrelation of Dosha and Dhatu}

"Dosha are the potential energies form of the body, they activate and enable the different structural substances in the body like "Dhatu" to exhibit their normal actions. "Dosha" by present in "Dhatus" enable them to perform their functions. "Dhatu" is the gross structure which is responsible for the shape and structure of the different organs like heart, lung, leg, arm etc. which make the bulk of the tissue of the human being and bear-support the body but their actions are regulated by potential energy which is present in them, that potential internal energy is a "Dosha" which is a Physiological entity that can't observed by using the microscope or with naked eye while the "Dhatu" can observed easily by microscope even with naked eye. "Dhatu is in matter form having a gross structure in contrary Dosha is the unobserved extent microscopic potential energies form of the body that present within the "Dhatu" and so. It is observed that externally viewed gross structure of Pillars of house bear and support the building, actually it is not so but the specific internal potencies capacity enable that gross structures to bear and support the building and if this type of capacity diminished, that incapable them to bear and support the house than after that could be breakdown. In the same way "Ras, Raktadi Dhatus" exhibit their action on the basis of their normal internal potential state that is "Dosha" 14, 15

Up to this, I have just focused on general description of the "Dosha". Know we see what should be the Actual meaning of the "Dosha" terminology by the different ancient and current author's point of the view than after we integrate it in globally accepted language. In Sanskrit literature "Dosha" means fault, vitiation or impurity, while in Ayurveda point of view it is pertain to the three biological aspects "Vata", "Pitta" and "Kapha" respectively.

According to Siddhant Nidan, Tatvadarshini

The aspect which are by vitiating with their own fault or due to any other factor, become enable to vitiate the Body and mind all of sudden, they are recognized as a "Tridosha"16

According to Madhukosh Vyakya

Though they are responsible for the formation of "Prakriti" at the time of the union of the "Shukra-Shonita, they have a capacity to develop vitiation in the body independently. So called as a "Dosha" 17

\section{According to Ashtanga Samgraha}

Dosha are those in which their normal quality and quantity responsible for the growth of the body in contrary in their abnormal quantity and quality responsible for destroying of the body. $^{18}$

According to the decision of "Tridosha Charcha Parishad" held in 1935 in BHU

"Dosha" are those which are responsible for normal functioning of the body and mind, regulate and control the all the Psycho physiological process and having a capacity to vitiate independently. ${ }^{19}$

Concluded integrated and globalized terminology of "Dosha" on the basis of above description

"Dosha are the biological complex integral potential aspects of our body derived from the relative predominance of the basic building block elements, in their normal status in our body they maintain the homeostasis in contrary in their abnormal status they tend to develop deformities in our body by disturbing the homeostatic mechanism, it is difficult to prove them physically, they are expressed by their attributes and functions, it means that they are physiological entities.

\section{DISCUSSION}

As per my knowledge most of students in the recent era who are entering in the Ayurveda stream become frustrated and confused with the Ayurveda fundamental principles and unable to grasp it and they maintaining the frustration Aura throughout his/her life which indirectly making them inactive in Ayurveda Practice. Because they are totally newer to those concepts which are totally philosophical and deep to be understand. They have no proper idea of it as they came from science stream, in which they haven't come across with those ancient concepts and nomenclatures. So if we provide them some information regarding the Ayurveda history and some conceptual 
information right from their primary to secondary education level it may reduce some frustration and may improve some thinking skills and there may be no chance of confusion because they may have some proper idea of that concepts before entering the stream like modern science students have. So I request the HRD, AYUSH and CCIM to consider it for the improvement of the Ayurveda education. As per as time changes there is a need to upgrade ourselves and our science to withstand with the time. If we fail in up gradation, become backward. So as per science evolution we should use some recent science knowledge and apply it in the form of integrative way for understanding the Ayurveda deep Concepts. This approach may create some interest in students to understand the Ayurveda Concepts. It totally depends on teacher's knowledge.

\section{CONCLUSION}

Ayurveda's proper knowledge enable us to maintain the healthy person's health and for the alleviating the diseased status of the body, due to some educational travesty most of Ayurveda Scholar can't understanding the Physiology, Pathology and Pharmacokinetics of the Ayurveda and ultimately failing to fulfill the Ancient science Aim. In the light of the recent scientific advancement it may be easily understood by providing the basic information regarding its concepts before entering in the main stream and by integrating ancient science concepts with the proper western science and using the globally accepted terminology which may improve our thinking skills regarding its concept and it in term make us compatible to use it in our clinical practice in right way to fulfill the Ayurveda Aim.

\section{REFERENCES}

1. Mittwede M, Ayurveda as a science: Reflection on the understanding of Ayurvedic concepts, Abhinava Dhanvantari Journal of Ayurveda, Jan-Feb-Mar 2014; 1(1): 46-52

2. Narayana J, Teaching reforms required for Ayurveda, JAIM. 2010 Apr-jun; 1(2):150-157

3. Gangadharan G, Ayurveda education in india, Abhinava Dhanvantari Journal of Ayurveda, Jan-Feb-Mar 2014; 1(1): 29-36

4. Patwardhan K, History of the discovery of the blood circulation: Unrecognized contribution of the Ayurveda Masters Advances in Physiological education, published in 1 June 2012, Vol 36 no 77-82 DOI: 10.1152/ advance. 00123.2011

5. Rapolu Sunil Buchiramulu, Piyush Kumar Tripathi. A valuable explanation of the cardiovascular system by ancient Ayurvedic science pioneers. Int. J. Res. Ayurveda Pharm. 2014;5(3):384-389 http://dx.doi. org/10.7897/22774343.05379
6. http://www.article.economictimes.indiatimes.com/20150622/news/63709137 1 international-yoga-education-hrdminister-smriti-irani Date last accessed: 06/17/2016.

7. Murthi S, Astangasamgraha, English translation, Vol 1,2, Krishnadas academy, Varanasi, reprint 2009, Suthrastana, chapter-20.

8. Acharya JT, Sushruta Samhita, Chaukhambha Surbharati Prakashan, Varanasi, India, 1994, The Chaukhambha Ayurvijnan Granthmala no.42, Suthrastana, chapter 21.

9. Murthy KRS, Sharangdhara Samhita of English translation, Chaukhambha orientalia, Varanasi, 2009, Purvakhand 5.

10. Pandey G, the Caraka Samhita of Agnivesha, $5^{\text {th }}$ edition, Varanasi, india: Chaukhambha Sanskrit Sansthana, Vol.1 and 2, The Kashi Sanskrit series no.194, Suthrastana, chapter-26, verse 12.

11. Pandey G, the Caraka Samhita of Agnivesha, $5^{\text {th }}$ edition, Varanasi, india: Chaukhambha Sanskrit Sansthana, Vol.1 and 2, The Kashi Sanskrit series no.194, Suthrastana, chapter-1, verse 12 .

12. Lad Vasant, Text book of Ayurveda: Fundamental principles of Ayurveda, vol.1, The Ayurvedic press, Albuquerque, New Mexico, first edition 2002, ISBN- 13:978-1-883725-07-5

13. Thite CM, Principles of Ayurvedic treatment-twenty gunas, Available http://www.aagamayurveda.com/Article\%20vimshati\%20G unas.htm Date last accessed: 23/02/2016.

14. Pandya D, Astangahridaya, Publisher: Ashvin B Shah, saraswat pustak bhandar, Ahmedabad, $2^{\text {nd }}$ edition 1999 , Page 209-210.

15. Hirlekar PS, Shaarir Tatva Darshan, Printed by TM Patil, Saraswati Mudranalaya of the hanuman vyayam prasarak mandal, Amraoti (Berar), 21-2-1942, Page 12-25.

16. Varma S, Yadav J, Sharir Kriya Vigyan, Chaukhambha Orientale, Varansi, ISBN: 978-81-7637-131-5, Page 15.

17. Parmar D, Madhav Nidan, Gurjar Vidhyoday Vyakhya, Publication: Saraswati Pustak Bhandar, Amdavad, Edition:2001-02, Madhukosh Commentary on $1^{\text {st }}$ Chapter Slok no 14, Page no 119 ,

18. Murthi S, Astangasamgraha, English translation, Vol 1,2, Krishnadas academy, Varanasi, reprint 2009, Suthrastana, chapter-19.

19. Gaur SK, Sharir Kriya Vigyanam, Publisher: Naath Pustak Bhandar, Rohtak, Printed by Suvira Mudranalaya, Rohtak.

\section{Cite this article as:}

Rapolu Sunil. An educational problem in Ayurveda field - How can we sort out it: A review. Int. J. Res. Ayurveda Pharm. Jul Aug 2016;7(Suppl 3):24-26 http://dx.doi.org/10.7897/22774343.074150

Disclaimer: IJRAP is solely owned by Moksha Publishing House - A non-profit publishing house, dedicated to publish quality research, while every effort has been taken to verify the accuracy of the content published in our Journal. IJRAP cannot accept any responsibility or liability for the site content and articles published. The views expressed in articles by our contributing authors are not necessarily those of IJRAP editor or editorial board members. 